EMILIA SOROKO

KATARZYNA AdAMCZYK

PAWEE KLEKA

BARBARA JANKOWIAK

Uniwersytet im. Adama Mickiewicza

w Poznaniu

\title{
MENTALNE WZORCE RELACYJNE JAKO PREDYKTORY STATUSU ZWIĄZKU STUDIUJĄCYCH KOBIET
}

ABSTRACT. Soroko Emilia, Adamczyk Katarzyna, Kleka Paweł, Jankowiak Barbara, Mentalne wzorce relacyjne jako predyktory statusu związku studiujących kobiet [Mental Relationship Patterns as Predicators of the Relationship Status of Studying Women]. Studia Edukacyjne nr 47, 2018, Poznań 2018, pp. 231-243. Adam Mickiewicz University Press. ISSN 1233-6688. DOI: 10.14746/se.2018.47.15

The article analyses relationship patterns as predictors of relationship status (having $v$ s not having a partner) among female university students. Inner relationship patterns were identified on the basis of written statements on significant relations. The statements were obtained through the Relationship Anecdotes Paradigm (RAP), which allows the acquisition of autobiographic records of narrative nature on personally significant interpersonal relations. The results of the analysis based on the concept of Core Conflictual Relationship Theme (CCRT) helped predict whether a respondent has a partner thanks to only one category of relationship patterns - the desire of the self to feel well and comfortably, to have a sense of stability, to feel happy and self-satisfied, triggered in the context of referring to a significant interpersonal relation in the narratives. The other aspects of the patterns - responses of the other to the self's desire and the response of the self to the reactions of the other - do not markedly affect the prediction of the relationship status.

Key words: relation patterns, singles, relationship status, Core Conflictual Relationship Theme (CCRT), Relationship Anecdotes Paradigm (RAP)

Studentki będąc w okresie przejścia pomiędzy późną adolescencją a wczesną dorosłością ${ }^{1}$ konstruują własną biografię, dokonując wielu wyborów życiowych także w obszarze relacji intymnych. Dla Eriksona wczesna dorosłość

${ }^{1}$ Na przykład, według Erika Homburgera Eriksona adolescencja to okres między 12/13 - 18/20 rokiem życia a wczesna dorosłość od 19. do 25. roku życia; zob. E.H. Erikson, Dzieciństwo i społeczeństwo, Poznań 1997. Daniel Lewinson używa pojęcia „okres przejściowy” na czas 
to okres rozwiązywania kryzysu intymność versus izolacja i tworzenia (bądź nie) znaczącej, intymnej więzi z drugą osobą ${ }^{2}$. Natomiast, w okresie adolescencji tworzone są związki preintymne, których główną funkcją jest kształtowanie się gotowości do wchodzenia w bliskie związki w okresie dorosłości oraz wspomaganie procesu formowania się tożsamości ${ }^{3}$. Status związku ${ }^{4}(\mathrm{tzn}$. posiadanie vs brak partnera życiowego) - a więc bycie w relacji intymnej vs bycie singlem - stanowi ważny dylemat głównie okresu wczesnej dorosłości, ale także okresu dojrzewania. W populacji młodzieży akademickiej współwystępują zadania wczesnej dorosłości i późnej adolescencji. Jak wynika z badań nad uwarunkowaniami życia w pojedynkę, przyczyny braku partnera życiowego nie zawsze są jednostce znane ${ }^{5}$, choć może ona tworzyć własne koncepcje (uzasadnienia) aktualnego statusu związku. Z kolei, bycie w związku jest efektem dokonanego wyboru o byciu z drugą osobą, a ponieważ partnerzy nie są połączeni więzami krwi, to poczucie wzajemnej bliskości oraz więzi jest rezultatem ich wzajemnych deklaracji (decyzji) i prowadzi do zobowiązań, nie zawsze mających swoje umocowanie instytucjonalne (np. w przypadku związków kohabitacyjnych) ${ }^{6}$. Uwarunkowania braku partnera życiowego stanowią konstelację wielu powiązanych ze sobą czynników o charakterze psychologicznym, społecznym, demograficznym i kulturowym ${ }^{7}$.

W niniejszej pracy analizie poddano predykcyjną rolę mentalnych wzorców relacyjnych, aby przewidzieć status związku, czyli posiadanie versus nieposiadanie partnera życiowego ${ }^{8}$. Wzorce relacyjne - jako określone tendencje dotyczące przebiegu intymnych relacji z innymi ludźmi, obejmujące początki, trwanie i zakończenie relacji - można rozpatrywać zarówno w perspektywie

między 17. a 22. rokiem życia, wczesna dorosłość od 22. do 45. roku życia; zob. D.J. Lewinson, A Conception of Adult Development, American Psychologist, 1986, 41(1), s. 2-13.

${ }^{2}$ E. H. Erikson, (1997), Dzieciństwo i społeczeństwo; tenże, Dopetniony cykl życia, Poznań 2002; tenże, Tożsamość a cykl życia, Poznań 2004.

${ }^{3}$ K. Piotrowski, J. Wojciechowska, B. Ziółkowska, Rozwój nastolatka. Późna faza dorastania, [w:] Niezbędnik dobrego nauczyciela, red. A.I. Brzezińska, Warszawa 2014, s. 26.

${ }^{4}$ Pojęcia "status związku" (relationship status) używamy za Lehmann i współpracownikami, mając na myśli stan relacyjny, czyli to, czy ktoś identyfikuje siebie jako osobę będącą w związku z drugą osobą lub nie; jest to pojęcie precyzyjniejsze pod względem realnego relacyjnego funkcjonowania osób niż bardziej klasyczne rozróżnienie na rodzaje stanu cywilnego, szczególnie kiedy badamy młodzież akademicką; por. V. Lehmann i in., Satisfaction with Relationship Status: Development of a New Scale and the Role in Predicting Well-Being, Journal of Happiness Studies, 2015, 16, s. 169-184.

${ }^{5}$ K. Palus, Uwarunkowania braku partnera życiowego w percepcji młodych dorostych żyjacych w pojedynke, Psychologia Rozwojowa, 2011, 16, 1, s. 57-71; tenże, Wybrane psychologiczne uwarunkowania braku partnera życiowego w okresie wczesnej dorostości, Poznań 2010.

${ }^{6}$ Por. B. Jankowiak, K. Kuryś-Szyncel, Zwiazki intymne jako autorskie projekty życia - próba konceptualizacji ponowoczesnych wzorców relacji, Studia Edukacyjne, 2015, 37, s. 257-273.

${ }_{7}$ K. Palus, Wybrane psychologiczne uwarunkowania braku partnera.

${ }^{8}$ Por. V. Lehmann i in., Satisfaction with Relationship Status. 
interpersonalnej (zewnętrznej - jak relacje przebiegają w płaszczyźnie społecznej), jak i intrapsychicznej (wewnętrznej - jak postrzegane i przeżywane są relacje interpersonalne oraz jakie niekoniecznie świadome oczekiwania co do przebiegu tych relacji żywią osoby) ${ }^{9}$. Wzorce relacyjne rozumiane intrapsychicznie są pochodnymi schematów relacyjnych i dlatego determinują gotowość do wchodzenia w relacje społeczne, postrzegania własnych pragnień, reakcji innych i poczucia szansy na własne zaspokojenie w określony przewidywalny sposób.

Jedną z ważnych kategorii pozwalających opisać wewnętrzne wzorce relacyjne są reprezentacje relacji z obiektem, które tworzą podatność na określony sposób funkcjonowania w związkach interpersonalnych, zakorzenioną w doświadczeniach z innych znaczących relacji, które cechowały się określonymi tendencjami do bliskości i odrębności. Zgodnie z psychodynamiczną teorią relacji z obiektem Kernberga ${ }^{10}$, uważa się, że funkcjonowanie $\mathrm{w}$ ważnych związkach jest zdeterminowane poziomem dojrzałości reprezentacji mentalnych relacji z obiektem. Reprezentacje te powstają głównie we wczesnym dzieciństwie jako efekt interakcji doświadczeń relacyjnych z opiekunem, jak i konstytucjonalnych (np. temperamentalnych) i manifestują się w postaci oczekiwań (fantazji, pragnień, myśli, uczuć) na temat przebiegu relacji z ważnymi osobami w życiu, a także $\mathrm{w}$ dalszej kolejności wpływają na funkcjonowanie interpersonalne. Będąc częścią struktury kognitywno-afektywnej osobowości, są relatywnie trwałe i wyznaczają automatyczne przetwarzanie informacji o relacjach, szczególnie tych, w których zaangażowane są emocje (por. problematyka mentalizacji) ${ }^{11}$. Pełnią $\mathrm{z}$ jednej strony funkcje regulacji psychicznej, a z drugiej powodują, że określone zachowania powtarzają się (przeniesienie i przymus powtarzania) ${ }^{12}$. W psychologii klinicznej korzysta się z koncepcji kluczowych konfliktowych wzorców relacyjnych (Core Conflictual Relationship Theme - CCRT ${ }^{13}$ ), która dzieli przebieg relacji (szczególnie $\mathrm{w}$ aspekcie reprezentacji czy wyobrażenia o relacji) na trzy komponenty: 1) pragnienia kierowane do obiektu (WS, wish of self), 2) antycypowane i spo-

${ }^{9}$ E. Soroko, Internal relationship patterns in borderline and neurotic personality organization: An analysis of self-narratives, Polish Journal of Applied Psychology, 2014, 12, 3, s. 9-28.

${ }_{10}$ O.F. Kernberg, Object relation theory and technique, [w:] Textbook of psychoanalysis, red. E.S. Person, A.M. Cooper, G.O. Gabbard, London 2005 s. 57-76; tenże, Borderline personality disorder and borderline personality organization: psychopathology and psychotherapy, [w:] Handbook of personality disorders. Theory and practice, red. J.J. Magnavita, New Jersey 2004, s. 92-119.

${ }^{11}$ D. Górska, L. Cierpiałkowska, Mentalizacja jako stan i jako cecha - perspektywa strukturalno-procesualna, [w:] Mentalizacja z perspektywy rozwojowej i klinicznej, red. L. Cierpiałkowska, D. Górska, Poznań 2016.

${ }^{12}$ S. Freud, W kwestii dynamiki przeniesienia, [w:] S. Freud, Technika terapii, Warszawa $1911 / 2007$.

${ }^{13}$ P. Crits-Christoph i in., Consistency of interpersonal themes for patients in psychotherapy, Journal of Personality, 1994, 62, 4. 
strzegane odpowiedzi obiektu (RO, response of object) oraz 3) reakcje self (RS, response form self). Trzy komponenty w ramach CCRT pozwalają obserwować dynamikę intrapsychiczną, uaktywnianą w ważnych relacjach, szczególnie dostępną w materiale werbalnym, przy opowiadaniu o znaczących doświadczeniach relacyjnych.

Wzorce relacyjne często ujawniają się w wypowiedziach, ale ich poznanie najczęściej wymaga interpretacji, na przykład: „,zawsze w związku dochodzi do takiego momentu, w którym się okazuje, że on mnie wykorzystał". Wypowiedź ta odnosi się do określonego uogólnienia (,zawsze ${ }^{\prime \prime}$ ), spostrzeżenia znaczącego punktu (,takiego momentu“) oraz swoistego zrozumienia („on mnie wykorzystał"), które ma charakter obronnego uporządkowania przykrości obecnej w doświadczeniu. Choć osoba może dostrzec pewną powtarzalność, zwykle nie rozpoznaje dokładnej swoich motywów ani konsekwencji tych doświadczeń.

Wewnętrzne wzorce relacyjne mogą wyjaśniać, jak osoba doświadcza interpersonalnych relacji z drugą osobą (np. czego pragnie, czego oczekuje) i mogą mieć związek z tym, czy ktoś w rzeczywistości ma partnera życiowego czy żyje w pojedynkę, ponieważ mogą tworzyć ku temu określone predyspozycje o intrapsychicznym (reprezentacja mentalna) charakterze. Biorąc pod uwagę wagę zadań rozwojowych w okresie później adolescencji oraz wczesnej dorosłości, charakterystyka wewnętrznych wzorców relacyjnych może wyznaczać charakter doświadczeń interpersonalnych i pośrednio prowadzić do pozostawania w związku lub życiu w pojedynkę. Można założyć zatem, że mentalne wzorce relacyjne tworzą osobowość jednostki, która wyznacza możliwości indywidualne w zdolności do zakładania i utrzymywania trwałych oraz zażyłych relacji miłosnych ${ }^{14}$. Spójne poczucie self wyznacza zarówno szacunek dla siebie, radość i zdolność do osiągania przyjemności $\mathrm{w}$ relacjach z innymi, przyczynia się do realizowania pragnień i celów długoterminowych. Natomiast, spójne i zintegrowane poczucie innych przyczynia sie do zdolności do udanych relacji i integracji z innymi. Zintegrowane poczucie self i innych umożliwia osiągnięcie zdolności do dojrzałej współzależności z innymi. Wiąże się bowiem ze zdolnością do wchodzenia i tworzenia uczuciowych więzi z innymi, przy jednoczesnym utrzymywaniu autonomii i spójności własnej osoby ${ }^{15}$. Podobnie Critchfield i Benjamin ${ }^{16}$ pokazują, że adaptacyjne wzorce relacyjne współwystępują z przywiązaniem bezpiecznym, prowadząc do pozytywnego obrazu siebie i otwartości w zaangażo-

14 F.E. Yeomans, J.F. Clarkin, O.F. Kernberg, Psychoterapia skoncentrowana na przeniesieniu w leczeniu zaburzeń osobowości borderline. Podręcznik kliniczny, Kraków 2015, s. 24.

15 Tamże.

${ }^{16}$ K.L. Critchfield, L.S. Benjamin, Assessment of repeated relational patterns for individual cases using the SASB-based Intrex questionnaire, Journal of Personality Assessment, 2010, 92, 6. 
waniu w świat społeczny. Pozytywność wzorców relacyjnych (zdolność do doświadczania satysfakcji w relacjach z innymi) uważana jest za ważny wskaźnik rozwoju osobowości ${ }^{17}$.

\section{Cel badań}

Stanowi go analiza wzorców relacyjnych jako predyktorów statusu związku (posiadania vs braku partnera). Pytanie dotyczyło zatem, czy pewne ukształtowane w głównej mierze na wczesnych etapach rozwojowych oczekiwania co do relacji mogą pozwalać przewidywać to, czy ktoś jest w związku czy żyje bez partnera. Ściślej mówiąc, postawiono hipotezę, że składowe wzorców relacyjnych - zarówno własne potrzeby, obraz reakcji drugiej osoby na te pragnienia, a także własne odpowiedzi na reakcje innych - są predyktorami statusu relacji (tj. posiadania vs braku partnera). Oczekiwano, że 1) osoby z dużym nasileniem pragnień libidinalnych (WS5, WS6, WS7, WS8), 2) osoby mające poczucie, że obiekt zaspokaja ich pragnienia (RO6, RO7, RO8), oraz 3) osoby pozytywnie reagujące na odpowiedzi obiektu (RS1, RS3, RS5) będą z większym prawdopodobieństwem w związkach. Podstawą tej hipotezy jest założenie, że pozytywność elementów wzorca relacyjnego, rozumianych jako oczekiwanie pozytywnego przebiegu relacji, sprzyja młodzieży akademickiej (biorąc pod uwagę ich psychospołeczną sytuację i zadania rozwojowe) wchodzeniu w relacje miłosne. Jest to redukcyjne założenie, gdyż nie uwzględnia w wystarczającym stopniu obecności konfliktów wewnętrznych (np. ktoś ma pragnienia antylibidinalne ranienia innych lub dystansowania się od nich, ale właśnie będąc w związkach je realizuje). Jednocześnie wydaje się, że we wczesnej dorosłości i późnej adolescencji, szczególnie w okresie studiowania, pozytywność oczekiwań co do przebiegu relacji interpersonalnej będzie skutkować jej podejmowaniem i deklaracjami związanymi ze statusem, który można określić jako bycie w związku.

\section{Zmienne i narzędzia badawcze}

Wewnętrzne wzorce relacyjne to mentalne reprezentacje (modele) relacji z ważnymi osobami, które odzwierciedlają wzór przeniesieniowy (wynikający z dawnych doświadczeń z pierwszymi opiekunami w dzieciństwie) i które są formułowane w postaci oczekiwań na temat przebiegu relacji z ważnymi osobami w życiu dorosłym. Wzorce relacyjne traktowane są tutaj zatem jako

${ }_{17}$ M. Cierpka i in., Stereotypical relationship patterns and psychopathology, Psychotherapy and Psychosomatics, 1998, 67. 
elementy struktury psychicznej, które nie są podatne na samoopis (podkreśla się bowiem, że dotyczą organizacji umysłu, która jest nieświadoma, choć ma manifestujące się na zewnątrz konsekwencje, dlatego wzorzec może być częściowo świadomy), badano je więc przez wywoływanie autonarracji i analizę jej treści. Analizowano trzy komponenty wzorców relacyjnych w ujęciu kluczowych konfliktowych wzorców relacyjnych (Core Conflictual Relationship Theme - CCRT ${ }^{18}$ ), a mianowicie pragnienie self kierowane do obiektu (wish of self, WS), odpowiedź obiektu (response from the object, RO) oraz odpowiedź self na odpowiedź obiektu (response from self, RS), które stanowiły sekwencję przebiegu relacji interpersonalnych. Aby uzyskać uogólniony (kluczowy) wzorzec, zebrano od każdej osoby uczestniczącej w badaniu cztery opowieści o różnych (dowolnych) relacjach z jej autobiografii.

Status związku badano za pomocą kwestionariusza demograficznego i zamieszczonego w nim pytania: "Czy ma Pan/Pani aktualnie partnera życiowego?" Osoby, które odpowiedziały przecząco zaliczono do grupy osób żyjących w pojedynkę, natomiast osoby które odpowiedziały „Tak“ zaliczono do grupy osób aktualnie posiadających partnera, tworzących aktualnie relację miłosną.

\section{Procedura badawcza}

Narzędzia badawcze w wersji elektronicznej przesłano studentom UAM w Poznaniu wszystkich wydziałów i kierunków studiów w formie linku do badania internetowego. Były to zarówno kwestionariusze samoopisowe (niesprawozdawane $\mathrm{w}$ tym artykule) oraz pisemne zadanie do wykonania dotyczące zrelacjonowania doświadczeń relacyjnych. Studenci byli zapraszani do badań listami elektronicznymi. Zaproszenie zawierało informacje o celach i procedurze badania. Ponadto, studenci byli zapewnieni o poufności oraz że ich adresy mailowe użyte będą tylko dla celów tego badania. Uzyskane dane zostały następnie poddane analizie treści z wykorzystaniem metody sędziów kompetentnych, statystycznemu opracowaniu oraz interpretacji.

Wewnętrzne wzorce relacyjne identyfikowano na podstawie pisemnych wypowiedzi uzyskanych od osób badanych dotyczących ważnych relacji. Wypowiedzi uzyskano w paradygmacie anegdot relacyjnych (Relationship Anegdotes Paradigm - RAP ${ }^{19}$ ). Jest to metoda pozwalająca na uzyskanie materiału autobiograficznego o narracyjnym charakterze na temat znaczących osobiście relacji interpersonalnych. W naszych badaniach zastosowana była

\footnotetext{
${ }^{18}$ P. Crits-Christoph i in., Consistency of interpersonal themes, s. 499-526.

${ }^{19} \mathrm{~L}$. Luborsky, The relationship anecdotes paradigm (RAP) interview as a versatile source of narratives, [w:] Understanding transference: The core conflictual relationship theme method, red. L. Luborsky, P. Crits-Christoph, Washington, DC 1998, s. 109-120.
} 
następująca instrukcja: Prosimy, abyś opowiedziat/a o takich zdarzeniach z innymi osobami, które sa dla Ciebie osobiście ważne, które w jakiś sposób poruszyły Cię lub które uważasz za pewna sytuacje problemowa. Możesz opowiedzieć historie o obecnych lub przeszłych wydarzeniach, ale niech każde z tych czterech wydarzeń bedzie różne i odrębne od siebie. Opowiadając o tych wydarzeniach, spróbuj wskazać: (1) kiedy to zdarzenie miało miejsce, (2) kto byt ważna dla Ciebie osoba, (3) co i kto powiedział lub zrobit i co Ty powiedziateś/aś lub zrobiłeś/aś, oraz (4) jak i kiedy zdarzenie się zakończyło. Spróbuj opowiedzieć o tych zdarzeniach w taki sposób, aby inni mogli lepiej Cię poznać, mieć prawdziwe wyobrażenie o Tobie. Opowiadaj tylko o tym, o czym naprawde chcesz, a na każde opowiadanie przeznacz od połowy do jednej strony formularza. Uzyskany $\mathrm{w}$ ten sposób materiał autobiograficzny relacyjny został zanalizowany przez sędziów kompetentnych (2 osoby przeszkolone w kodowaniu materiału werbalnego tego typu, mające za sobą bogaty trening w ocenie wzorców tą metodą i przygotowanie z zakresu psychoterapii psychodynamicznej) pod kątem wzorców relacyjnych. W określaniu treści wzorców oparto się na koncepcji głównych (rdzeniowych) konfliktowych tematów relacyjnych Crits-Christopha i Luborsky'ego ${ }^{20}$ (zob. tab. 1).

Treść wzorców mentalnych

\begin{tabular}{|l|l|l|}
\hline \multicolumn{1}{|c|}{ Pragnienie self (WS) } & \multicolumn{1}{|c|}{ Reakcja obiektu (RO) } & \multicolumn{1}{c|}{ Reakcja self (RS) } \\
\hline $\begin{array}{l}\text { WS1 być niezależnym, kon- } \\
\text { trolować siebie, manifesto- } \\
\text { wanie siebie }\end{array}$ & $\begin{array}{l}\text { RO1 silny, niezależny, } \\
\text { szczęśliwy, nie reaguje, jest } \\
\text { osobno }\end{array}$ & $\begin{array}{l}\text { RS1 pomocny, otwarty, } \\
\text { rozumiejący }\end{array}$ \\
\hline $\begin{array}{l}\text { WS2 przeciwstawić się, } \\
\text { ranić i kontrolować innych }\end{array}$ & RO2 kontrolujący, surowy & $\begin{array}{l}\text { RS2 mało otwarty, nie ro- } \\
\text { zumie, zamknięty, nie lubi } \\
\text { innych }\end{array}$ \\
\hline $\begin{array}{l}\text { WS3 być kontrolowanym, } \\
\text { krzywdzonym i nieodpo- } \\
\text { wiedzialnym, być jak inni, } \\
\text { być wspomaganym }\end{array}$ & $\begin{array}{l}\text { RO3 zmartwiony, zranio- } \\
\text { ny, zależny, lękliwy, roz- } \\
\text { złoszczony, pozbawiony } \\
\text { kontroli }\end{array}$ & $\begin{array}{l}\text { RS3 respektowany i akcep- } \\
\text { towany, czuję się odprężo- } \\
\text { ny, kochany, szczęśliwy, } \\
\text { szanowany, akceptowany }\end{array}$ \\
\hline $\begin{array}{l}\text { WS4 być zdystansowanymi } \\
\text { i unikać konfliktów }\end{array}$ & $\begin{array}{l}\text { RO4 zły, mało wiarygodny, } \\
\text { niekompetentny }\end{array}$ & $\begin{array}{l}\text { RS4 chce oponować } \\
\text { i krzywdzić innych }\end{array}$ \\
\hline $\begin{array}{l}\text { WS5 być blisko i akcepto- } \\
\text { wać, akceptować, szano- } \\
\text { wać, być otwartym, zaufać }\end{array}$ & $\begin{array}{l}\text { RO5 odrzucający i przeciw- } \\
\text { stawiający się, nie ufa, nie } \\
\text { szanuje, nie rozumie, nie } \\
\text { lubi, dystansuje się, niepo- } \\
\text { mocny, przeciwny }\end{array}$ & $\begin{array}{l}\text { RS5 samokontrolujący się } \\
\text { i pewny siebie, niezależny, } \\
\text { pewny siebie, kontrolujący }\end{array}$ \\
\hline
\end{tabular}

${ }^{20}$ P. Crits-Christoph i in., Consistency of interpersonal themes, s. 499-526. 


\begin{tabular}{|l|l|l|}
\hline $\begin{array}{l}\text { WS6 być kochanym i ro- } \\
\text { zumianym, szanowanym, } \\
\text { lubianym, akceptowanym }\end{array}$ & $\begin{array}{l}\text { RO6 pomocny, nie rani, jest } \\
\text { pomocny, współpracujący }\end{array}$ & $\begin{array}{l}\text { RS6 bezsilny, pozbawiony } \\
\text { kontroli, bezradny, niepew- } \\
\text { ny, zależny }\end{array}$ \\
\hline $\begin{array}{l}\text { WS7 czuć się dobrze i kom- } \\
\text { fortowo, mieć poczucie } \\
\text { stabilności, komfortu, czuć } \\
\text { się szczéśliwym i zadowo- } \\
\text { lonym z siebie }\end{array}$ & $\begin{array}{l}\text { RO7 lubi mnie, kocha, sza- } \\
\text { nuje, lubi, daje niezależność }\end{array}$ & $\begin{array}{l}\text { RS7 rozczarowany i mający } \\
\text { depresję, rozzłoszczony, } \\
\text { zazdrosny, niekochany }\end{array}$ \\
\hline $\begin{array}{l}\text { WS8 pozyskiwać innych } \\
\text { i pomagać innym, być do- } \\
\text { brym, poprawiać siebie }\end{array}$ & $\begin{array}{l}\text { RO8 rozumiejący, otwarty, } \\
\text { akceptujący }\end{array}$ & $\begin{array}{l}\text { RS8 lękliwy i zawstydzo- } \\
\text { ny, pełen lęku i poczucia } \\
\text { winy }\end{array}$ \\
\hline
\end{tabular}

Opracowano na podstawie: L. Luborsky, M. Barrett, The core conflictual relationship theme: a basic case formulation method, [w:] Handbook of psychotherapy case formulations, red. T.D. Eells, London 2007.

W ramach analizy każdego z trzech komponentów korzystano z kategorii standardowych, które wynikały z analiz empirycznych (analiz skupień wykonanych przez autorów metody) i które dzieliły każdy z komponentów na osiem jakościowo różnych kategorii ${ }^{21}$. Sędziowie kompetentni w niniejszym badaniu mieli określić nasilenie każdej kategorii dla każdego z trzech aspektów (8 kategorii $\times 3$ aspekty) dla każdej z 4 opowiedzianych historii. Wynik ogólny dla każdego z 24 elementów wzorca był średnią ocen dwóch sędziów ze wszystkich czterech historii (średnia z 4 historii) i mógł przyjmować wartości od 0 (brak) do 5 (bardzo duże nasilenie). Zgodności między sędziami mierzone współczynnikiem alfa Krippendorffa wynosiły od 0,4 do 0,68. Można zatem przyjąć, że w wyniku analizy uzyskuje się uogólniony schemat relacji interpersonalnej, składający się z pragnień self, odpowiedzi innego i odpowiedzi self, który dzięki temu, że pochodzi z analizy kilku historii odnosi się do pewnego uogólnionego, prawdopodobnie powtarzalnego wzorca relacyjnego. Mówi nam to zatem o zawartości typowych reprezentacji aspektów relacji z obiektem, zarówno tych związanych z self (pragnienia i reakcje własne) jak i obiektu (antycypowana, odczuwana reakcja ze strony obiektu na pragnienia self).

\section{Osoby badane}

Wstępnie do analiz zakwalifikowano wyniki 59 osób (grupa niekliniczna, studenci różnych kierunków uniwersyteckich). Pochodziły one z ponad czterotysięcznej grupy osób, które podjęły się wypełnienia ankiet, z czego 429

${ }^{21}$ L. Luborsky, M. Barrett, The core conflictual relationship theme: a basic case formulation method, [w:] Handbook of psychotherapy case formulations, red. T.D. Eells, London 2007, s. 105-135. 
(327 kobiet i 102 mężczyzn) osób zareagowało wypełnieniem części samoopisowych, ale tylko owe 59 z nich ukończyło część wymagającą napisania czterech historii o ważnych relacjach interpersonalnych. Były to więc najwytrwalsze osoby uczestniczące $\mathrm{w}$ badaniach. W próbie tej znalazły się tylko osoby heteroseksualne i niezamężne. Ponieważ w jednej grupie - wśród osób, które pozostawały w związku - nie było mężczyzn, do dalszej analizy włączono 51 wypowiedzi kobiet w wieku od 18 do 27 lat (średni wiek: $M=22$; $S D$ $=1,96)$, które wypełniły kwestionariusze oraz wypowiadały się pisemnie na temat czterech ważnych relacji interpersonalnych, $w$ jakie były lub są zaangażowane. Kobiety pozostające w związku $(n=30)$ oraz kobiety nieposiadające partnera $(n=21)$ nie różniły się wiekiem $(t(37)=0,67 ; p=0,508)$ oraz rokiem studiowania (chi2 $(4, n=51)=4,71 ; p=0,318)$.

\section{Analiza statystyczna danych i wyniki}

Wzorce relacyjne jako predyktory statusu związku. W celu udzielenia odpowiedzi na pytanie: czy można przewidzieć status związku na podstawie znajomości wzorców relacyjnych wykorzystano regresję logistyczną z użyciem walidacji krzyżowej. Wyniki przeprowadzonej analizy pozwoliły w badanej próbie przewidywać posiadanie partnera z dokładnością wynoszącą $63 \%\left(\mathrm{CI}_{.95}: 48-76 \%\right)$, na podstawie tylko jednej kategorii wzorców relacyjnych - a mianowicie w pragnieniu self, aby czuć się dobrze i komfortowo, mieć poczucie stabilności, czuć się szczęśliwym i zadowolonym z siebie (WS7), które uruchamiane jest $\mathrm{w}$ ważnej relacji interpersonalnej. Pozostałe elementy wzorców - ani odpowiedzi innego na pragnienia self (RO) ani odpowiedź self na reakcje innego (RS) - nie wpływają na predykcję w sposób istotny $(p>0,10)$.

Uzyskany wynik o istotnym wpływie pragnienia WS7 można interpretować $\mathrm{w}$ ten sposób, że wraz ze wzrostem natężenia pragnienia self WS7 o 1 punkt, ponad dwa i pół raza rośnie szansa posiadania partnera $(\mathrm{OR}=2,67$, $\left.\mathrm{CI}_{.95}: 1,31-6,05\right)$. Innymi słowy, przy braku pragnienia (WS7 $=0$ ) prawdopodobieństwo posiadania partnera jest bliskie losowemu (53,3\%), wraz ze wzrostem do 1 pkt wynosi ono już $94 \%$, a dla wartości powyżej 2 jest prawie pewne $(99,6 \%)$. Wiedząc, że pragnienie może przyjąć wartość od 0 do 5, można zauważyć, że już jego niewielkie nasilenie (1 lub 2 punkty na 5 możliwych oznaczają bowiem nieznaczne nasilenie pragnienia) zwiększa prawdopodobieństwo opisywania się jako osoba posiadająca partnera, będąca $\mathrm{w}$ związku. Wynik ten podkreśla znaczenie tego pragnienia $\mathrm{w}$ tym, żeby rzeczywiście być w związku z drugą osobą (wybierać, wiązać się, opisywać się jako osoba $w$ relacji). 


\section{Dyskusja i ograniczenia badania}

Wyniki naszych badań pokazują znaczenie pragnienia, aby czuć się dobrze i komfortowo, mieć poczucie stabilności, komfortu, czuć się szczęśliwym i zadowolonym z siebie (WS7) w przewidywaniu życia z partnerem lub w pojedynkę. Innymi słowy, kobiety, które mają - uruchamiane przy sprawozdawaniu o ważnych relacjach, więc prawdopodobnie uruchamiane i w realnych relacjach - uogólnione pragnienie czucia się $\mathrm{w}$ tych relacjach komfortowo, będą tworzyć związki z mężczyznami. Rozwinięte reprezentacje mentalne własnych pragnień oraz fakt, że zdaniem osób właśnie tymi pragnieniami kierują się one w relacjach, stanowią dobre predyktory statusu związku. Prezentowane badania sugerują, iż w okresie studiów partnera posiadają te osoby, które mają w miarę klarowne (w sensie możliwe do zakomunikowania w serii opowieści o relacjach) reprezentacje własnych pragnień czucia się dobrze. Innymi słowy, można przypuszczać, że osoby posiadające partnera to osoby posiadające silniej odczuwaną potrzebę intymności, bliskości, przynależności i wyobrażają sobie, że w związku jest możliwe zaspokojenie tych potrzeb. Uzyskane wyniki, rozumiane jako wskazujące na związek między potrzebą intymności a osiąganiem tej intymności $\mathrm{w}$ związkach, pozostają w zgodzie z pracami E.H. Eriksona, który zdefiniował intymność jako „zdolności odczuwania jako dominującej potrzeby i autotelicznej wartości egzystencjalnej takich stanów i sytuacji jak: więź psychiczna, zespolenie fizyczne, bliskość i wspólnota" 22. Dodatkowo, klarowne reprezentacje własnych pragnień czucia się dobrze wydają się być powiązane ze skonsolidowaną tożsamością, wyrażającą się „w uczuciu zadomowienia w swoim ciele, jak w domu, świadomości tego, dokąd się zmierza i wewnętrznej pewności antycypowanego rozpoznania przez tych, którzy się liczą" ${ }^{23}$. Wydaje się zatem prawdopodobne - jak wskazywał E.H. Erikson w odniesieniu do związków między tożsamością a intymnością - iż świadomość własnych pragnień co do intymnych relacji sprzyja ich nawiązywaniu i posiadaniu partnera. Opisywane pragnienia self mogą stać się elementem projektu biograficznego, będącego procesem składającym się ze świadomych wyborów i decyzji na temat kształtu własnej drogi rozwojowej ${ }^{24}$.

W badaniach oczekiwaliśmy nie tylko, iż libidinalne pragnienia, ale również że inne pozytywne elementy wzorców relacyjnych, jak odpowiedzi innego oraz odpowiedzi self, będą mieć znaczenie dla realnych wyborów relacyjnych. Oczekiwania te nie potwierdziły się. Co więcej, nie znaleziono też

${ }^{22}$ Za: L. Witkowski, Rozwój i tożsamość w cyklu życia. Studium koncepcji Erika H. Eriksona, Toruń 2000, s. 43.

${ }^{23}$ E.H. Erikson, Tożsamość a cykl życia, s. 115.

${ }^{24}$ B. Jankowiak, K. Kuryś-Szyncel, Zwiazki intymne jako autorskie projekty życia, s. 257-273. 
żadnych innych, choć niezakładanych tu explicite powiązań między wzorcami relacyjnymi a statusem związku, na przykład że przy silnej reakcji negatywnej self $\mathrm{w}$ postaci rozczarowania relacją zwiększa się prawdopodobieństwo braku partnera. Jest nam dość trudno wyjaśnić te zaskakujące rezultaty, szczególnie że wynika z nich, iż postrzegana reakcja innych na własne pragnienia oraz własne reakcje $\mathrm{w}$ odniesieniu do relacji nie wiążą się $\mathrm{z}$ funkcjonowaniem interpersonalnym badanych.

W tym kontekście pojawia się bardziej podstawowe pytanie o relację między wzorcami mentalnymi (o charakterze uogólnionych elementów struktury psychicznej) a realnym zachowaniem. Nie ulega wątpliwości, że metoda analizy wzorców relacyjnych odnosi się do świata wewnętrznego (reprezentacji, oczekiwań, wyobrażeń nakładanych na rzeczywistość), dlatego możemy być przekonani, że wiedza o komponentach wzorców relacyjnych jest wiedzą o zjawiskach nieobserwowanych, choć mających potencjał regulacyjny względem zachowań interpersonalnych. Można spodziewać się, że udział struktur psychicznych $\mathrm{w}$ formowaniu zachowań będzie zapośredniczony innymi mechanizmami psychologicznymi, jak na przykład regulacją emocji, poziomem stresu, czy poziomem kompetencji społecznych. Ważnym dalszym kierunkiem badań i refleksji w tym obszarze byłoby poszukiwanie zmiennych pośredniczących między strukturą psychiczną a wyborami życiowymi czy deklaracjami dotyczącymi statusu relacji.

Dalej pojawia się też pytanie o zasadność używania analizy wzorców relacyjnych (z takim naciskiem na ich intrapsychiczny charakter) w badaniu populacji ogólnej pod kątem funkcjonowania społecznego. Możliwe, że zależności między strukturami psychicznymi a ich manifestowaniem się w zachowaniach społecznych są inne w populacji nieklinicznej niż w klinicznej. W populacji osób z zaburzeniami psychicznymi rola świata wewnętrznego $\mathrm{w}$ postrzeganiu relacji interpersonalnych (pobudzone pragnienia, nieadekwatność pragnień do okoliczności, mechanizm projekcji, rola nieświadomości w funkcjonowaniu) może być większa niż w nieklinicznej. Uzasadnienie przedstawianych hipotez wywodzi się bowiem z myślenia psychodynamicznego, odwołującego się do psychologii klinicznej, psychopatologii i psychoterapii. Stawia nas to $\mathrm{w}$ obliczu znaczącej nierozwiązanej tutaj kwestii: czy obszarze w psychologii klinicznej i psychologii człowieka zdrowego stawiać możemy podobne hipotezy opierając się na podobnych modelach teoretycznych i w jakim zakresie do ich badania używać można podobnych narzędzi.

Ograniczeniem badania jest mała liczba osób badanych, ale uzyskanie istotności predykcji w tej grupie sugeruje, że efekt ten byłby wyraźniejszy wraz ze wzrostem liczebności grupy. $W$ badaniach zanalizowano po cztery opowieści pochodzące od każdej badanej osoby, co stanowi już próbkę 204 narracji, na podstawie których oceniano komponenty wzorców relacyjnych. 
Uzyskanie materiału słownego od dużej grupy osób jest trudne, co pokazuje spadek liczby pełnych odpowiedzi wraz ze wzrostem wymagań względem uczestników badań. Pewnym mankamentem, ale jednocześnie ważną obserwacją co do konsekwencji sposobu badania (zachęcanie do opowiadania historii), jest też przypadkowe ograniczenie grupy badawczej do kobiet, dla których chęć opowiadania o sobie może być znacząco łatwiejsza niż dla mężczyzn.

\section{BIBLIOGRAFIA}

Cierpka M., Strack M., Benninghoven D., Staats H., Dahlbender R., Pokorny D., Körner A., Stereotypical relationship patterns and psychopathology, Psychotherapy and Psychosomatics, 1998, 67.

Critchfield K.L., Benjamin L.S., Assessment of repeated relational patterns for individual cases using the SASB-based Intrex questionnaire, Journal of Personality Assessment, 2010, 92, 6.

Crits-Christoph P., Demorest A., Muenz L.R., Baranackie K., Consistency of interpersonal themes for patients in psychotherapy, Journal of Personality, 1994, 62, 4.

Erikson E.H., Dzieciństwo i społeczeństwo, Dom Wydawniczy Rebis, Poznań 1997.

Erikson E.H., Dopetniony cykl życia, Dom Wydawniczy Rebis, Poznań 2002.

Erikson E.H., Tożsamość a cykl życia, Zysk i S-ka Wydawnictwo, Poznań 2004.

Freud S., W kwestii dynamiki przeniesienia, [w:] S. Freud, Technika terapii, Wydawnictwo KR, Warszawa 1911/2007.

Górska D., Cierpiałkowska L., Mentalizacja jako stan i jako cecha - perspektywa strukturalno-procesualna, [w:] Mentalizacja z perspektywy rozwojowej i klinicznej, red. L. Cierpiałkowska, D. Górska, Wydawnictwo Naukowe PWN, Poznań 2016.

Jankowiak B., Kuryś-Szyncel K., Związki intymne jako autorskie projekty życia - próba konceptualizacji ponowoczesnych wzorców relacji, Studia Edukacyjne, 2015, 37.

Kernberg O.F., Borderline personality disorder and borderline personality organization: psychopathology and psychotherapy, [w:] Handbook of personality disorders. Theory and practice, red. J.J. Magnavita, John Wiley \& Sons, New Jersey 2004.

Kernberg O.F., Object relation theory and technique, [w:] Textbook of psychoanalysis, red. E.S. Person, A.M. Cooper, G.O. Gabbard, American Psychiatric Publishing, London 2005.

Lehmann V., Tuinman M.A., Braeken J., Vingerhoets A.J.J.M., Sanderman R., Hagedoorn M., Satisfaction with Relationship Status: Development of a New Scale and the Role in Predicting Well-Being, Journal of Happiness Studies, 2015, 16(1).

Lewinson D.J., A Conception of Adult Development, American Psychologist, 1986, 41(1).

Luborsky L., The relationship anecdotes paradigm $(R A P)$ interview as a versatile source of narratives, [w:] Understanding transference: The core conflictual relationship theme method, red. L. Luborsky, P. Crits-Christoph, American Psychological Association, Washington, DC 1998.

Luborsky L., Barrett M., The core conflictual relationship theme: a basic case formulation method, [w:] Handbook of psychotherapy case formulations, red. T.D. Eells, The Guilford Press, London 2007.

Palus K., Wybrane psychologiczne uwarunkowania braku partnera życiowego w okresie wczesnej dorosłości, Wydawnictwo Naukowe Wydziału Nauk Społecznych, Poznań 2010. 
Palus K., Uwarunkowania braku partnera życiowego w percepcji młodych dorostych żyjacych w pojedynke, Psychologia Rozwojowa, 2011, 16, 1.

Piotrowski K., Wojciechowska J., Ziółkowska B., Rozwój nastolatka. Późna faza dorastania, [w:] Niezbędnik dobrego nauczyciela, red. A.I. Brzezińska, Instytut Badań Edukacyjnych, Warszawa 2014.

Soroko E., Internal relationship patterns in borderline and neurotic personality organization: An analysis of self-narratives, Polish Journal of Applied Psychology, 2014, 12, 3.

Witkowski L., Rozwój i tożsamość w cyklu życia. Studium koncepcji Erika H. Eriksona, Wydawnictwo Wit-Graf, Torun 2000.

Yeomans F.E., Clarkin J.F., Kernberg O.F., Psychoterapia skoncentrowana na przeniesieniu w leczeniu zaburzeń osobowości borderline. Podręcznik kliniczny, Polskie Towarzystwo Psychoterapii Psychodynamicznej, Kraków 2015. 
